\title{
Performance of Nellore females in tropical pastures during the rainy season when supplemented with molasses blocks
}

\section{Desempenho de fêmeas nelore em pastagens tropicais, durante a estação chuvosa quando suplementadas com blocos de melaço}

\author{
Henrique Moreira Lopes ${ }^{1}$; Maria Lucia Pereira Lima²; Gabriel Carletti Zilião ${ }^{3}$; João \\ Alberto Negrão ${ }^{4}$; Flávia Fernanda Similii; Bianca Vilela Pires ${ }^{1}$; Lenira El Faro ${ }^{2}$
}

\begin{abstract}
The objective of this study was to measure the effect of supplementation with molasses blocks compared with conventional mineral supplementation (with specific formulations for the rainy and dry season) in 92 7-month-old Nellore heifers (Experiment 1) and 40 primiparous 31-month-old Nellore cows (Experiment 2) in Marandu grazing areas. The following measurements were obtained: weight, supplement intake, blood urea and glucose in heifers (Experiment 1), supplement intake, cow weight, body score, calf weight and ruminal temperature and drinking events in primiparous females (Experiment 2). The average molasses block intake was $242 \mathrm{~g}$ day $^{-1}$ per heifer, with an average weight gain of $0.290 \mathrm{~kg} \mathrm{day}^{-1}$; the heifers who consumed the molasses blocks were heavier during the rainy season ( $\mathrm{P}<0.05$; Experiment 1). In Experiment 2, molasses block intake varied from 77 to $821 \mathrm{~g} \mathrm{day}^{-1}$ per primiparous female, and the average intake in the control group was between 100 and $370 \mathrm{~g} \mathrm{day}^{-1}$. The primiparous females given molasses blocks displayed lower weight loss due to calving $(\mathrm{P}<0.05)$ and retained higher body scores at 150 days postpartum $(\mathrm{P}<0.05)$. Ruminal temperature $(\mathrm{P}<0.05)$ and drinking events $(\mathrm{P}<0.05)$ were higher in primiparous Nellore females given molasses blocks. Overall, molasses blocks effectively increased Nellore female performance during the rainy season in Marandu grass pastures.
\end{abstract}

Key words: Beef cattle. Grazing supplementation. Mineralised salt.

\section{Resumo}

Objetivou-se medir o efeito da suplementação utilizando blocos de melaço, em comparação à suplementação mineral convencional, em 92 novilhas Nelore de 7 meses de idade (Experimento 1) e 40 primíparas Nelore de 31 meses de idade (Experimento 2), com formulações específicas para épocas chuvosas ou secas em pastagens de capim Marandu. Também foram realizadas as seguintes medições: peso, consumo do suplemento, ureia e glicose em novilhas (Experimento 1) e consumo de suplemento, peso de vacas primíparas, condição corporal, peso de bezerros, temperatura ruminal e frequência da

1 Discentes, Curso de Mestrado do Programa de Pós-Graduação em Produção Animal Sustentável, Instituto de Zootecnia, Agência Paulista de Tecnologia dos Agronegócios, APTA, Secretaria de Agricultura e Abastecimento, SAA, Sertãozinho, SP, Brasil. E-mail: fazendaparaisodaserra@gmail.com; bianca2510@outlook.com

2 Pesquisadores, APTA, SAA, Sertãozinho, SP, Brasil.E-mail: lucia.plima@hotmail.com; flaviasimili@iz.sp.gov.br; lenira@iz.sp. gov.br

3 Discente, Curso de Graduação em Agronomia, Fundação Educacional de Ituverava, FE, SP, Brasil. E-mail: gabriel.ziliao@ hotmail.com

4 Prof., Departamento de Ciências Básicas, Faculdade de Ciência Animal e Engenharia de Alimentos, Universidade de São Paulo, USP, Pirassununga, SP, Brasil. E-mail: jnegrao@usp.br

* Autor correspondente 
ingestão hídrica nas primíparas (Experimento 2). O consumo médio dos blocos de melaço, por novilha, foi de $242 \mathrm{~g} \mathrm{dia}^{-1}$, com ganho de peso de $0,290 \mathrm{~kg} \mathrm{dia}^{-1}$. As novilhas que consumiram os blocos contendo melaço tiveram maiores pesos durante a estação chuvosa $(\mathrm{P}<0,05)$ (Experimento 1). No experimento 2, a ingestão de blocos de melaço variou de 77 a $821 \mathrm{~g} \mathrm{dia}^{-1}$ por primípara, e a ingestão média no tratamento controle foi entre 100 e $370 \mathrm{~g} \mathrm{dia}^{-1}$. As fêmeas primíparas tratadas com blocos de melaço apresentaram menor perda de peso devido ao parto $(\mathrm{P}<0,05)$, e mantiveram escores corporais mais elevados aos 150 dias pós-parto $(\mathrm{P}<0,05)$. A temperatura ruminal $(\mathrm{P}<0,05)$ e a frequência do consumo de água $(\mathrm{P}<$ $0,05)$ foram maiores nas primíparas Nelore do tratamento com blocos de melaço. $\mathrm{O}$ uso de blocos de melaço incrementam o desempenho de fêmeas Nelore durante a estação chuvosa em pastagens de capim Marandu.

Palavras-chave: Gado de corte. Sal mineralizado. Suplementação em pastejo.

\section{Introduction}

Grazing cattle supplementation is strategic, since it is used to overcome mineral, energetic and protein deficiencies, and to improve animal performance and productivity. Mineral supplements, either granular or powdered, are provided to the animals by way of feeding troughs (or specific containers), and this procedure requires additional costs and demands for labor, tractors and fuel to deliver the mineral supplement. Additionally, granular or powdered supplements require protection from rain (roofs), mainly in tropical environments where precipitation is generally heavy and excessive moisture may cause damage to the supplement and increase the risk of excess intake of melted urea. Low moisture and cooked molasses blocks supplied in buckets decrease the labor required to deliver feed and are safe with regards to urea solubilisation (MENGISTU; HASSEN, 2017).

Urea molasses multi-nutrient blocks have been utilised as livestock feed supplements in a number of countries, and several studies report positive effects on productive and reproductive performance. These supplements also represent an attractive cost-benefit ratio, mainly if the molasses blocks are supplied in association with low-quality forage (AUBEL et al., 2011; JAYAWICKRAMA et al., 2013; STEPHENSON et al., 2016). Another use for molasses block supplements is to aid in grazing management. Cattle prefer to stay near the blocks, and thus forage intake will improve in that specific area. Moving the buckets alters grazing concentrations along with molasses supplements (BAILEY; JENSEN, 2008).

Growing heifers (for replacement) and primiparous cows are considerably nutrient demanding, mainly the latter due to growth, lactation and the expectation of novel reproduction. Since pastures represent a low cost to feed cattle, they are used all year round in tropical environments. The annual variation of climate in these regions affects pasture growth and quality. During the dry season, there is a reduced percentage of leaves and increased dead material (COSTA et al., 2005).

Measuring data from bovines exclusively on pastures is challenging, but some devices could aid in animal control. Lohölter et al. (2013) used an intra-ruminal device to measure the increase of ruminal temperature when cows were fed more energetic diets. Ruminal temperature increased in parallel with digestibility due to optimal rates of rumen fermentation (LOHÖLTER et al., 2013).

The objective of this study was to compare the effect of supplementation using molasses blocks with conventional mineral supplementation (both treatments with specific rainy and dry season formulations) in Nellore heifers and primiparous females in Marandu grazing areas. 


\section{Material and Methods}

The experiments were conducted at the Beef Cattle Research Center of the Animal Sciences Institute, in Sertãozinho, SP, Brazil. All procedures were performed in accordance with the Brazilian Guidelines for the Care and Use of Animals for Scientific and Educational Purposes of National Council for Control of Animal Experimentation (CONCEA, 2013).

The two experiments were conducted with Nellore females (heifers for Experiment 1 and primiparous cows for Experiment 2). The following treatments were used: (1) molasses blocks (Caltech-Cystalyx ${ }^{\circledR}$ ) with condensed molasses and minerals and (2) control treatment (supplement with a proteinated mixture during the dry season, and powdered mineralised salt, without energy or protein, during the rainy season; Table 1). The mineral-supplement intake of each group was controlled weekly by weighing the total offered product and the leftovers. In the molasses block treatment, pure salt $(\mathrm{NaCl})$ was also provided, ad libitum, in separate containers. Intake was constant during the entire experiment. The average $\mathrm{NaCl}$ intake was $21.0 \mathrm{~g}$ day $^{-1}$ per heifer (Experiment 1) and $28.0 \mathrm{~g} \mathrm{day}^{-1}$ per primiparous cow (Experiment 2).

Table 1. Composition of molasses block and control supplements used during the dry and rainy seasons.

\begin{tabular}{lcccc}
\hline & Dry season & \multicolumn{3}{c}{ Rainy season } \\
\hline & Molasses blocks & Control & Molasses blocks & Control \\
\hline Sugar (expressed as sucrose), \% & 30 & - & 35 & - \\
Crude oil \& fat, \% & 4 & - & 4 & - \\
Crude protein, \% & 30 & 50 & 12 & - \\
Protein equiv. of urea, \% & 18 & 29 & 8.7 & - \\
Crude ash, \% & 27 & - & 28 & 95 \\
Phosphorus, \% & 2 & 1.5 & 2.5 & 8 \\
Calcium, \% & 4 & 7 & 4 & 14 \\
Magnesium, \% & 1 & - & 1 & - \\
Sodium, \% & 2 & 5.7 & 2 & 13.7 \\
Vitamin A, IU & 100000 & - & 75000 & - \\
Vitamin D3, IU & 20000 & - & 15000 & - \\
Vitamin E, mg kg-1 & 250 & - & 150 & - \\
Iodine, mg kg-1 & 40 & 10 & 40 & 80 \\
Cobalt, mg kg-1 & 12 & 80 & 12 & 80 \\
Manganese, mg kg-1 & 1200 & - & 1200 & 1000 \\
Zinc, mg kg-1 & 1200 & 1000 & 1200 & 3500 \\
Selenium, mg kg-1 & 9 & 4.5 & 9 & 20 \\
Copper, mg kg-1 & 600 & 30 & 600 & 1400 \\
Urea (technically pure), g kg-1 & 30 & 45 & 62 & - \\
Sulfur, g kg-1 & - & 5 & - & 10 \\
\hline
\end{tabular}




\section{Experiment 1}

Experiment 1 lasted from June 2016 to October 2017. The maximum and minimum air temperature as well as rainfall were recorded daily (Figure 1). Pasture areas were two 14 ha paddocks; the paddocks were alternated every 28 days $(1.20$ UA/ha). Ninety-two weaned 7-month-old Nellore heifers with initial weight of $164.6 \mathrm{~kg}$ were used. The weight of the animals was determined monthly without fasting.
In order to measure urea and glucose blood serum levels, four blood samplings were conducted in 12 test heifers for each treatment, two of which were carried out during the dry season and two during the rainy season. The blood was collected directly from the jugular vein using Vaccutainer ${ }^{\circledR}$ tubes (BD Vacutainer, Franklin Lakes, NJ). Following collection, the blood was centrifuged, and the serum was transferred into Eppendorf tubes and frozen. The blood urea nitrogen (BUN) and glucose concentrations were measured using a diagnostic test kit (Labtest Diagnóstica SA, Lagoa Santa, MG, Brazil) that employed a colorimetric method.

Figure 1. Daily maximum and minimum environmental temperatures and rainfall during the dry season in 2016 (JunOct), the rainy season in 2016-17 (Nov-May) and the dry season in 2017 (Jun-Oct).

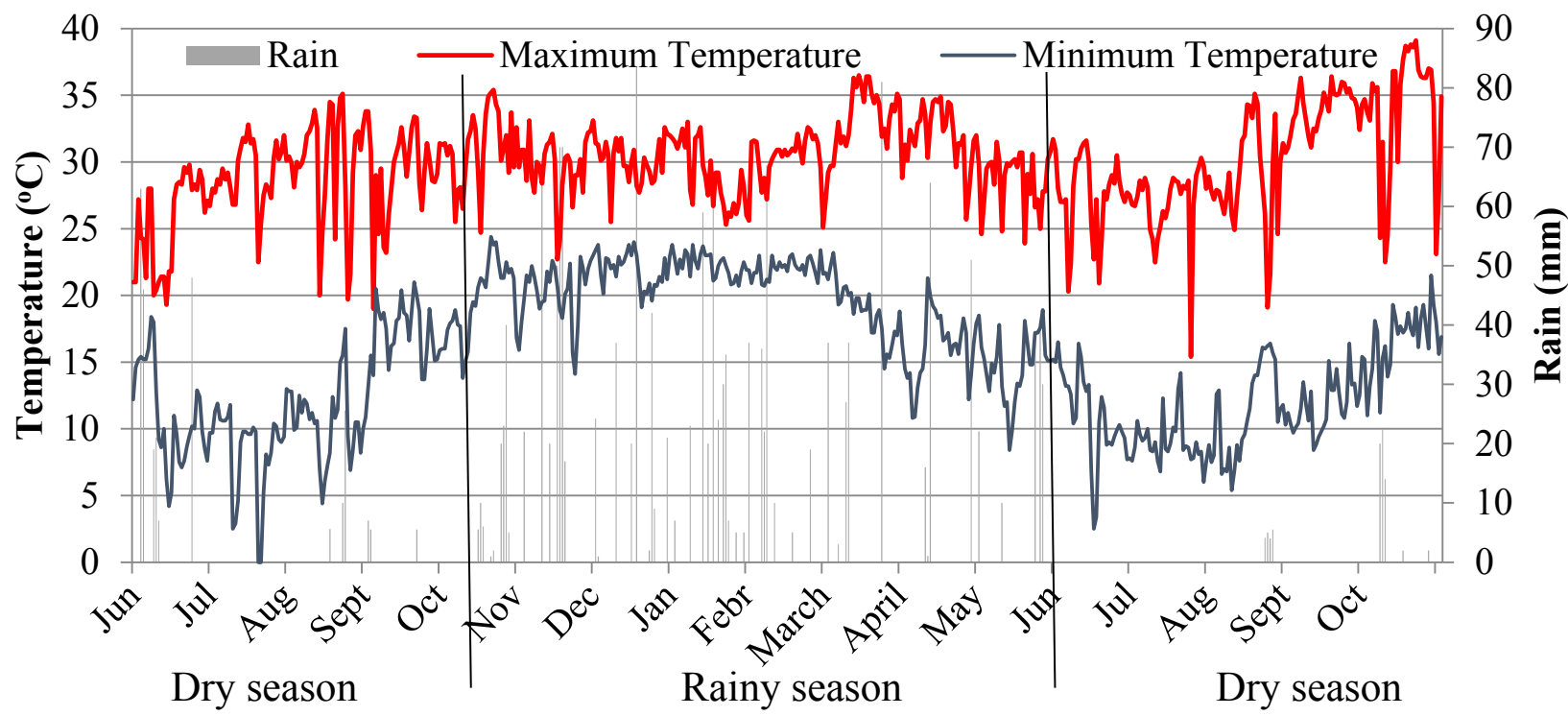

In order to measure urea and glucose blood serum levels, four blood samplings were conducted in 12 test heifers for each treatment, two of which were carried out during the dry season and two during the rainy season. The blood was collected directly from the jugular vein using Vaccutainer ${ }^{\circledR}$ tubes (BD Vacutainer, Franklin Lakes, NJ). Following collection, the blood was centrifuged, and the serum was transferred into Eppendorf tubes and frozen. The blood urea nitrogen (BUN) and glucose concentrations were measured using a diagnostic test kit (Labtest Diagnóstica SA, Lagoa Santa, MG, Brazil) that employed a colorimetric method.

All variables were analysed with the SAS program, using the MIXED procedure, in order to compare the heifer weight, BUN and glucose. The fixed effects comprised experimental treatment (supplement type), the month of data collection and the season (considering repeated measurements over time). When there was a significant interaction 
effect between weight and month, the weight was analysed separately for each month. Additionally, the adjusted means of the model were compared with the Tukey test $(\mathrm{P}<0.05$ was considered significant).

\section{Experiment 2}

Experiment 2 lasted from June 2016 to March 2017. The maximum and minimum air temperatures and rainfall were recorded daily (Figure 1). The pasture areas were two 12 ha paddocks; the paddocks were alternated every 28 days (1.68 UA/ha).

This experiment consisted of 40 primiparous 31-month-old Nellore females separated in weight groups: 350 to $400 \mathrm{~kg}, 401$ to $500 \mathrm{~kg}$ and greater than $500 \mathrm{~kg}$. Calvings took place from September 12th to November 13th, 2016 (62 days - two months, considered as September and October) in the experimental pastures.

Following parturition, the calves were managed on the pasture; they were weighed and individually identified by ear branding and also received standard newborn care. If the calves exhibited any injuries or wounds, diarrhea or other neonatal disease(s), they received daily care on the pastures on which they were raised. After 20 days of age, the calves were weighed every 28 days, in the morning, without separation from the mother, and their adjusted weights were calculated at 60, 100 and 150 days of age. The adjusted weight was calculated by subtracting the weight of the animal at a specific date by its weight at birth and dividing the obtained value by the animal's age in days. Subsequently, the body weight gain was multiplied by the number of adjusted days (60, 100 or 150) and added to the animal's weight at birth. At calving, 60, 100 or 150 days after parturition, the primiparous females were weighed without fasting and classified according to body condition scoring (BCS), from 1 to 9 , where 1 represented exceptionally skinny animals and 9 remarkably fat ones (NRC, 2000).
In order to monitor ruminal temperature, an indwelling and wireless data transmitting system (SmaXtec animal care GmbH, Graz, Austria) was used (GASTEINER et al., 2009). The measurement interval for temperature was $10 \mathrm{~min}$, continuously, and the stored data were transmitted using the ISMBand (433 MHz). Seven cows from the molasses block and 8 from the control treatment group received the orally administered intraruminal devices. The data were sent remotely and retrieved on the SmaXtec Company's website (<http://www. smaxtec.com/en/ $>$ ). Sudden drops in temperature indicated moments where the cow drank water. The frequency of drinking events was counted individually per cow every time the temperature dropped $0.8^{\circ} \mathrm{C}$ (in $10 \mathrm{~min}$ intervals).

Comparisons between cow body weight, parturition weight loss and BCS were conducted using the experimental treatment (supplement type), calf birth month, calf gender and the cow group as fixed effects. In order to compare the birth weight of the calves and the weights adjusted at 60, 100 and 150 days of age, the fixed effects comprised the treatments, birth month and gender.

The animals were considered the random effect, and the means adjusted by the model were compared using the Tukey test $(\mathrm{P}<0.05$ was considered significant). In order to analyse ruminal temperature, the entire database was processed with the SAS program. Every temperature decrease greater than $0.8^{\circ} \mathrm{C}$ was considered a water drinking event. Accordingly, frequency tables of these events were compared using the chi-squared test, and the treatment and time of day when the events took place as a fixed effect. In order to compare the ruminal temperature between treatments, all temperature drops that resulted from water ingestion were discarded. Further, the animals were regarded as the random effect, and the means adjusted by the model were compared using the Tukey test $(\mathrm{P}<0.05$ was considered significant). 


\section{Pasture evaluation for both experiments}

The pastures were sampled during the dry and rainy seasons to assess forage mass and the proportions of leaves, stems and dead material. In order to conduct the samplings, four $1.0 \mathrm{~m}^{2}$ metal squares were used to mark four different locations where the pasture was sampled. After collection, the material was weighed and separated into three batches that consisted of leaves, stems or dead material. All leaves with greater than 50\% dry (dead) surfaces were included in the 'dead material'.
The referred samples underwent drying in a forced-air oven at $65^{\circ} \mathrm{C}$. Afterwards, they were ground and dried at $105^{\circ} \mathrm{C}$ in order to determine the dry matter (DM) content. Calculations were conducted to determine forage mass, leaf mass and the proportions of the following components: leaf, stem and dead material (Table 2). Additionally, chemical composition, including crude protein (CP) and neutral detergent fibre (NDF), were determined and analysed according to the AOAC (1990), as shown in Table 3.

Table 2. Forage assessment: forage mass (Mass), leaf mass (Leaves) and proportion (\%) of leaves, stems and dead material (Dead), according to the experimental month and season, in Experiments 1 and 2.

\begin{tabular}{|c|c|c|c|c|c|c|c|c|c|c|}
\hline & \multicolumn{5}{|c|}{ Experiment 1} & \multicolumn{5}{|c|}{ Experiment 2} \\
\hline & \multicolumn{2}{|c|}{$\mathrm{Kg} \mathrm{DM} \mathrm{ha}^{-1}$} & \multicolumn{3}{|c|}{ Proportion $(\%)$} & \multirow{2}{*}{\multicolumn{2}{|c|}{$\begin{array}{l}\text { kg DM ha-1 } \\
\text { Mass Leaves }\end{array}$}} & \multicolumn{3}{|c|}{ Proportion $(\%)$} \\
\hline & Mass & Leaves & Leaves & Stem & Dead & & & Leaves & Stem & Dead \\
\hline \multicolumn{11}{|c|}{ September (2016) - Dry season } \\
\hline Pasture 1 & 5969 & 654 & 10.3 & 13.8 & 75.9 & 8814 & 849 & 9.6 & 25.5 & 64.9 \\
\hline Pasture 2 & 5118 & 783 & 14.7 & 18.0 & 67.3 & 9201 & 936 & 10.2 & 18.2 & 71.6 \\
\hline \multicolumn{11}{|c|}{ December (2016) - Rainy season } \\
\hline Pasture 1 & 3596 & 1717 & 46.0 & 30.7 & 23.3 & 6670 & 1477 & 22.1 & 17.4 & 60.5 \\
\hline Pasture 2 & 3799 & 1339 & 35.4 & 19.5 & 45.1 & 3991 & 1547 & 38.8 & 24.5 & 36.7 \\
\hline \multicolumn{11}{|c|}{ February (2017) - Rainy season } \\
\hline Pasture 1 & 5110 & 1380 & 25.3 & 20.9 & 53.8 & 5348 & 1548 & 28.9 & 37.9 & 33.2 \\
\hline Pasture 2 & 6496 & 1405 & 20.8 & 21.3 & 57.9 & 7476 & 2412 & 32.3 & 24.9 & 42.8 \\
\hline \multicolumn{11}{|c|}{ June (2017) - Dry season } \\
\hline Pasture 1 & 6736 & 754 & 11.2 & 36.8 & 52.0 & - & - & - & - & - \\
\hline Pasture 2 & 6065 & 820 & 12.0 & 33.5 & 54.5 & - & - & - & - & - \\
\hline \multicolumn{11}{|c|}{ September (2017) - Dry season } \\
\hline Pasture 1 & 5432 & 232 & 4.3 & 13.2 & 82.5 & - & - & - & - & - \\
\hline Pasture 2 & 5638 & 185 & 3.3 & 12.1 & 84.6 & - & - & - & - & - \\
\hline
\end{tabular}


Table 3. Pasture forage composition: crude protein (CP) and neutral detergent fibre (NDF) of the leaves, stems and dead material, according to the experimental month and season, in Experiments 1 and 2.

\begin{tabular}{|c|c|c|c|c|c|c|c|c|c|c|c|c|}
\hline & \multicolumn{6}{|c|}{ Experiment $1(\%)$} & \multicolumn{6}{|c|}{ Experiment $2(\%)$} \\
\hline & \multicolumn{2}{|c|}{ Leaves } & \multicolumn{2}{|c|}{ Stems } & \multicolumn{2}{|c|}{ Dead material } & \multicolumn{2}{|c|}{ Leaves } & \multicolumn{2}{|c|}{ Stems } & \multicolumn{2}{|c|}{ Dead material } \\
\hline & $\mathrm{CP}$ & NDF & $\mathrm{CP}$ & NDF & $\mathrm{CP}$ & NDF & $\mathrm{CP}$ & NDF & $\mathrm{CP}$ & NDF & $\mathrm{CP}$ & NDF \\
\hline \multicolumn{13}{|c|}{ September 2016 - Dry season } \\
\hline Pasture 1 & 7.2 & 70.7 & 4.0 & 78.7 & 3.2 & 75.5 & 9.0 & 62.9 & 3.4 & 73.9 & 2.2 & 81.9 \\
\hline Pasture 2 & 8.7 & 72.9 & 3.8 & 80.4 & 2.3 & 82.6 & 9.7 & 65.5 & 2.3 & 78.2 & 2.0 & 83.9 \\
\hline \multicolumn{13}{|c|}{ December 2016 - Rainy season } \\
\hline Pasture 1 & 12.1 & 62.8 & 7.3 & 70.0 & 2.6 & 80.3 & 8.5 & 68.4 & 4.6 & 76.3 & 3.3 & 80.8 \\
\hline Pasture 2 & 12.4 & 65.4 & 7.6 & 69.0 & 2.2 & 81.2 & 6.9 & 72.3 & 4.8 & 75.2 & 3.1 & 81.1 \\
\hline \multicolumn{13}{|c|}{ February 2017 - Rainy season } \\
\hline Pasture 1 & 11.0 & 61.5 & 5.1 & 76.0 & 3.7 & 81.7 & 7.8 & 69.0 & 4.5 & 76.4 & 3.4 & 77.3 \\
\hline Pasture 2 & 11.3 & 62.9 & 4.2 & 75.5 & 3.9 & 83.5 & 8.3 & 71.6 & 3.9 & 78.9 & 2.4 & 80.7 \\
\hline \multicolumn{13}{|c|}{ June 2017 - Dry season } \\
\hline Pasture 1 & 9.5 & 67.8 & 3.8 & 78.9 & 2.5 & 81.1 & - & - & - & - & - & - \\
\hline Pasture 2 & 10.2 & 68.7 & 4.3 & 77.8 & 2.5 & 79.1 & - & - & - & - & - & - \\
\hline \multicolumn{13}{|c|}{ September 2017 - Dry season } \\
\hline Pasture 1 & 9.0 & 62.9 & 3.4 & 73.9 & 2.2 & 81.9 & - & - & - & - & - & - \\
\hline Pasture 2 & 9.7 & 65.5 & 2.3 & 78.2 & 2.0 & 83.9 & - & - & - & - & - & - \\
\hline
\end{tabular}

\section{Animal care for both experiments}

Animal weight was determined monthly without fasting. In order to conduct the weighing procedure, both animal groups were led into a handling corral where they underwent vaccination and were provided other required medication, according to the farm's health calendar. Individual care was also offered as necessary.

\section{Results and Discussion}

Figure 2 presents supplement intake data. In Experiment 1 (Figure 2a), immediately after weaning the heifers and during the first dry season, the average molasses block and control treatment intakes were 190 and $101 \mathrm{~g} \mathrm{day}^{-1}$ per heifer, respectively. During the rainy season, the supplement intake was 200 and $65 \mathrm{~g}$ day $^{-1}$ per heifer, and during a second dry season, 372 and $125 \mathrm{~g}$ day $^{-}$ ${ }^{1}$ per heifer, respectively. There was a significant improvement in supplement intake at the end of the dry season (Figure 2a).

In Experiment 2 (Figure 2b), the average intake of the molasses blocks and control supplement were 380 and $122 \mathrm{~g} \mathrm{day}^{-1}$ per primiparous cow, respectively. There was increased intake at the end of the dry season that corresponded with increased environmental temperatures (Figure 1), which occurred when the calving period began. The averages of supplement intake during the dry and rainy seasons were 354 and $143 \mathrm{~g} \mathrm{day}^{-1}$ and 415 and $98 \mathrm{~g} \mathrm{day}^{-1}$ per primiparous cow, for the molasses block and control groups, respectively. 
Figure 2. Average supplement intake for heifers in Experiment 1 (a) and primiparous females in Experiment 2 (b).

(a)

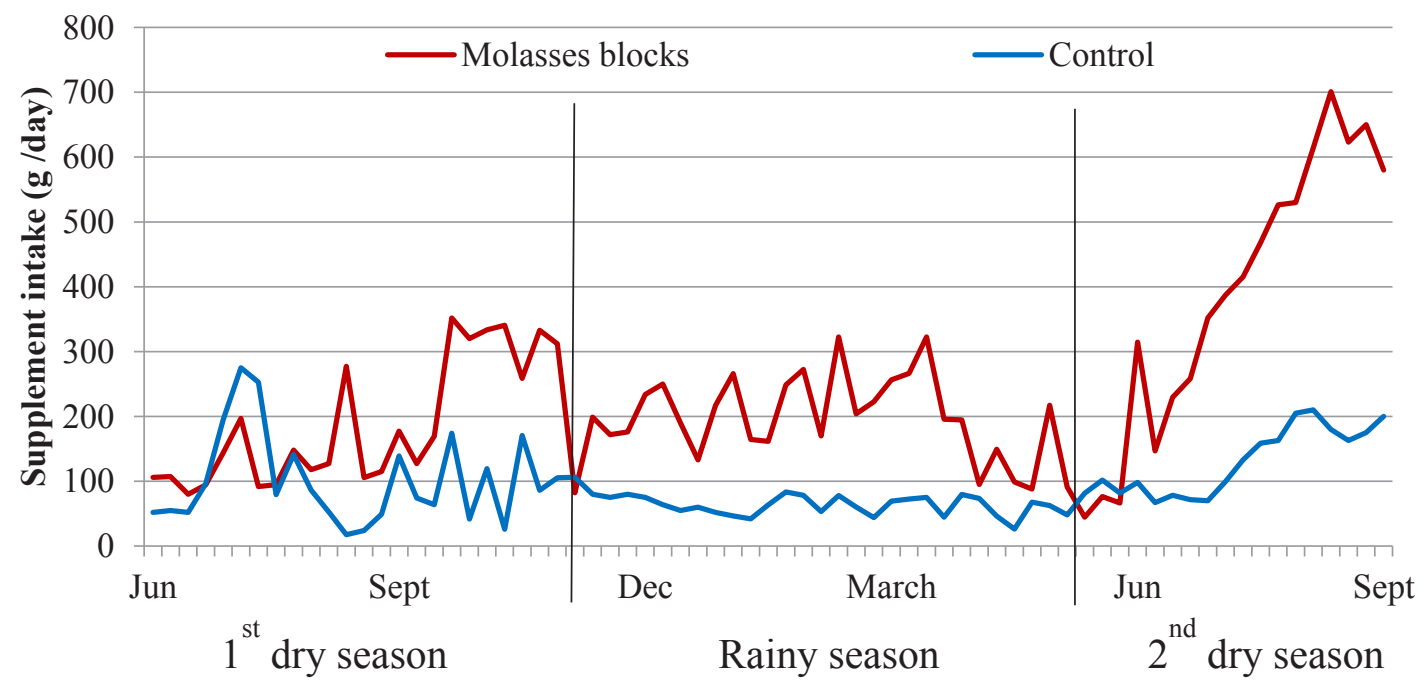

(b)

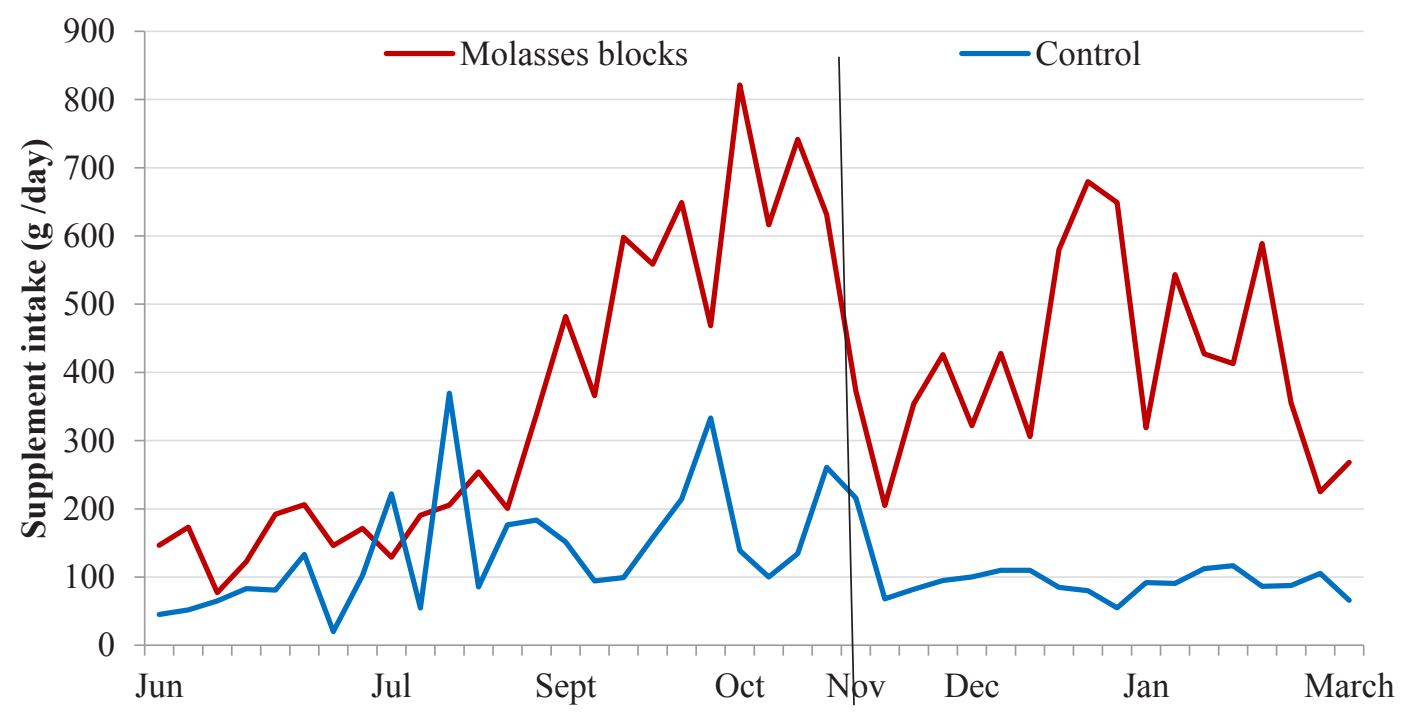

In Experiment 1, the initial heifer weights (at 7 months old) was $165 \mathrm{~kg}$. The weights for the animals in Experiment 1 are shown in Figure 3. There was a statistically significant effect of birth month $(\mathrm{P}<0.01)$, where the oldest heifers were heavier. After noting an interaction $(\mathrm{P}<0.01)$ between weighing month and live weight, weight comparison for each experimental month was performed (Figure 3). During the first dry season, differences in live weight were not observed $(\mathrm{P}>$ 0.05 ), even though animals from both treatments lost weight. As the rain regressed, pasture blooming ensured that the Nellore cattle rapidly recovered their weight. The molasses-block-supplemented heifers were significantly heavier during the rainy season, specifically in January, February, April and at the beginning of the second dry season in June ( $\mathrm{P}<0.05$ for each month). However, as the second dry season progressed, there was no difference in live weight between the molasses block and control groups. 
Figure 3. Mean live weight of the Nellore heifers during the entire experimental period (Experiment 1).

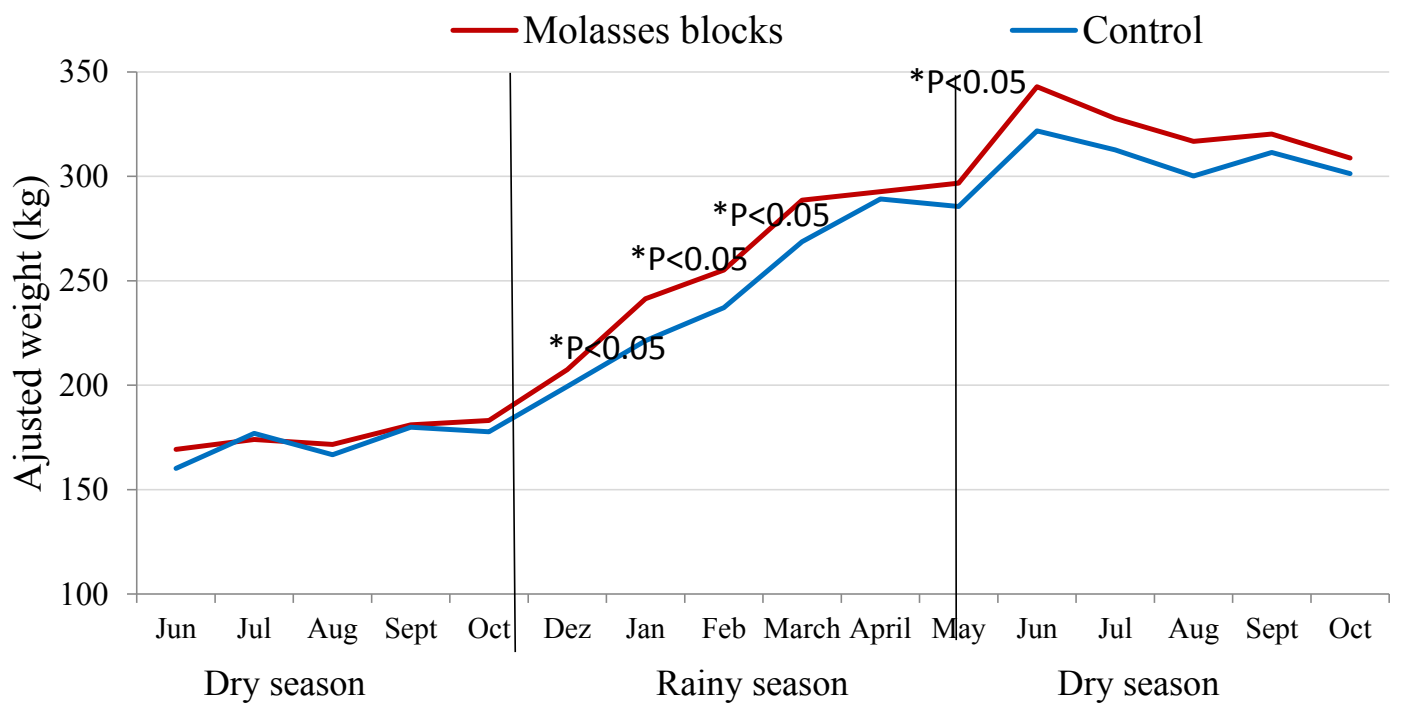

In Experiment 2, calvings took place during the dry season and the transition between the dry and rainy seasons. The primiparous cow body weights during the entire experiment are shown in Figure 4. There was no statistical difference $(\mathrm{P}>0.05)$ between treatments regarding live weight. Calving month affected cow weights only in the period before calving $(\mathrm{P}<0.05)$.

There was a significant effect $(\mathrm{P}<0.05)$ on body weight loss due to parturition. The primiparous cows in the molasses block group lost considerably less weight $(67.3 \mathrm{~kg})$ than those that received the control treatment $(74.1 \mathrm{~kg})$.

During the first dry season, the pastures retained $70-80 \%$ of dead material (Table 2), with $2.3-3.2 \%$ $\mathrm{CP}$ and $11-15 \%$ of leaves $(7.2-8.7 \%$ CP; Table $3)$, values typical of the dry season in tropical environments. The second dry season was worse than standard years; the percentage of leaves was below 5\%. Additionally, supplement intake increased substantially during this period in Experiment 1, although both heifer groups lost weight.

Figure 4. Mean body weights of the primiparous cows according to treatments during the experimental period (Experiment 2).

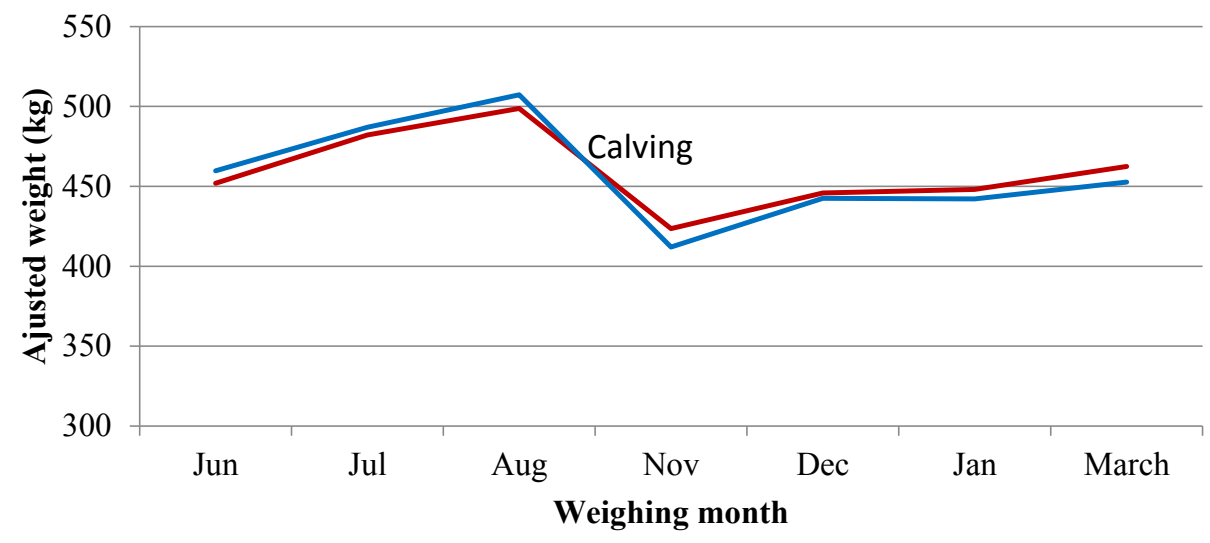

Molasses blocks $\quad$ Control 
In the transition period, when the rain began, the dry-season control treatment supplement experienced rain-related problems. When wet (or even partially moist), the product had an alternate smell and was rejected by the animals. Regarding the dangers related to urea solubilisation in the control supplement, due to episodes of heavy rain, the molasses block buckets were extremely stable during the transition period between the dry and rainy seasons.

There was significant BCS effect observed with regards to treatment. The animals that consumed the molasses block supplement displayed the highest ( $\mathrm{P}$ $<0.05)$ body scores only at 150 days postpartum (Table 4). The calving month did not affect BCS (P $>0.05)$.

Table 4. Mean ( \pm standard deviation) of cow body condition scores (BCS) from calving until 150 days postpartum for each experimental treatment (Experiment 2).

\begin{tabular}{lcccc}
\hline & Calving & 60 days & 100 days & 150 days \\
\hline Molasses blocks & $5.4 \pm 0.21$ & $5.2 \pm 0.22$ & $5.0 \pm 0.28$ & $5.5 \pm 0.17$ \\
Control & $5.5 \pm 0.21$ & $5.0 \pm 0.20$ & $4.9 \pm 0.26$ & $4.9 \pm 0.15$ \\
\hline P value (treatments) & 0.31 & 0.61 & 0.77 & 0.01 \\
P value (calving month) & 0.12 & 0.26 & 0.76 & 0.87 \\
\hline
\end{tabular}

The supplement intake increase at the end of the dry season (poor quality roughage) did not affect weight gain. These results are similar to those obtained in the study by Perdock and Leng (1990), where they investigated different concentrated supplements and ad libitum consumption of molasses blocks comprised of $41 \%$ sugar cane molasses and 15\% urea. They worked with 18-month-old Frisian heifers, and the offered roughage consisted of treated and untreated rice straw. Molasses block intake varied from $0.1-1.1 \mathrm{~kg}$ day $^{-1}$ per heifer (average of $0.4 \mathrm{~kg}$ day $^{-1}$ per heifer), depending on the phosphorus source. The ruminal ammonia values increased in parallel with the intake of molasses blocks without affecting weight gain.

Aubel et al. (2011) observed a lower intake of molasses-based blocks after the transition from plant winter dormancy to spring growth of native tallgrass. Using beef cows, the average intake of molasses blocks and salt supplement (granular) was $0.19 \mathrm{~g} \mathrm{day}^{-1}$ and $0.06 \mathrm{~kg}$ day $^{-1}$ per cow, respectively. These values are lower compared with the present work, where the average supplement intake was 415 $\mathrm{g}$ day $^{-1}$ per cow for the molasses blocks and $98 \mathrm{~g}$ day $^{-1}$ per cow for the control (mineral) supplement.

A previous study compared grazing patterns of non-lactating cows supplemented with range cakes with $20 \% \mathrm{CP}$, fed three times per week $\left(0.9 \mathrm{~kg}\right.$ day $^{-1}$ per cow), in an accessible terrain, and low-moisture molasses blocks with $30 \% \mathrm{CP}$, continually placed on steeper slopes at higher elevations. White salt blocks $(99.9 \% \mathrm{NaCl})$ were available for both treatment groups. The voluntary intake of the molasses blocks supplement was $318 \mathrm{~g} \mathrm{day}^{-1}$ per cow (BAILEY; JENSEN, 2008), which was lower than the intake reported in the present work $\left(380 \mathrm{~g} \mathrm{day}^{-1}\right)$.

Stephenson et al. (2016) worked with cows in large pastures and used supplementation with lowmoisture blocks $(25 \% \mathrm{CP})$; the main ingredients were cane molasses, rice bran, urea and soybean meal. Supplement intake was $0.55 \mathrm{~kg}$ per cow when the grass CP ranged from $3.7-5.4 \%$, values that are higher than that of the present study $\left(415 \mathrm{~g}\right.$ day $^{-1}$ per cow, with $12 \% \mathrm{CP}$ ) during the rainy season. 
Jayawickrama et al. (2013) studied cross-bred dairy cows who received hybrid napier grass (15$16 \% \mathrm{CP}$ ) and $1.0 \mathrm{~kg}$ of concentrate and rice straw $\mathrm{ad}$ libitum at night in Sri Lanka. The authors examined whether giving cows $300 \mathrm{~g}^{\text {day }}{ }^{-1}$ molasses blocks with $27.8 \% \mathrm{CP}$ improved voluntary rice straw intake. No difference was observed in dry mater intake and milk production (5.34 versus $5.66 \mathrm{~kg}$ of milk day ${ }^{-1}$ for molasses block and control groups, respectively).

Differences in calf body weight were not observed $(\mathrm{P}>0.05)$ when comparing the offspring of the cows in the molasses block and control groups (Table 5). Calf gender influenced the weight only at birth $(\mathrm{P}<0.01)$, but not at 60,100 or 150 days postpartum (Table 5).

Table 5. Mean ( \pm standard deviation) live body weight means of calves at birth (WB) and at 60 (W60), 100 (W100) and 150 (W150) days of age.

\begin{tabular}{lcccc}
\hline & WB, kg & W60, kg & W100, kg & W150, kg \\
\hline Molasses blocks & $34.2 \pm 1.2$ & $85.4 \pm 3.1$ & $117.3 \pm 3.7$ & $163.6 \pm 5.1$ \\
Control & $33.4 \pm 1.1$ & $84.9 \pm 2.5$ & $117.1 \pm 2.9$ & $161.1 \pm 4.1$ \\
\hline Value P (treatments) & 0.63 & 0.89 & 0.95 & 0.69 \\
Value P (calf gender) & 0.01 & 0.47 & 0.39 & 0.18 \\
\hline
\end{tabular}

Kalmbacher et al. (1995) analysed pregnant cows (4-year-old Brafords) that calved and then raised their calves on the range. Two molassesbased liquid supplements with $30 \% \mathrm{CP}$ were tested (93.4\% cane molasses and $6.6 \%$ urea versus $75 \%$ cane molasses, $22.3 \%$ cottonseed meal and $2.7 \%$ urea; values based on DM). The initial weights of the cows were 483 and $480 \mathrm{~kg}$, and the BCS were 5.4 and 5.5 for molasses urea and cottonseed supplements, respectively. After calving, the authors observed significant BCS losses (-1.3 and -1.7), and the final scores were 4.1 and 3.8, respectively. In accordance with the present study results, the cows supplemented with molasses blocks with urea exhibited a higher BCS 150 days after calving. Immediately after calving, both groups lost BCS, but the cows supplemented with molasses blocks returned to the same calving $\mathrm{BCS}$ values 150 days postpartum, while the control group displayed lower BCS (-0.61) at the same time.

Landblom et al. (2002) worked with cows that received $2.2 \mathrm{~kg}$ of corn and hay with $9 \% \mathrm{CP}$ before calving. Thirty and 60 days post-calving, the cows received hay with $19 \% \mathrm{CP}$. The average BCS was 5.9 before and 5.2 after calving and reached 4.4 at 127 days after calving. These results are similar to the present analysis 100 days after calving. On the other hand, and different from Landblom et al. (2002), our data corroborated the influence of the molasses blocks, which increased BCS.

The BUN levels (Figure 5a) were higher during the dry season $(\mathrm{P}<0.01)$. When compared with the rainy season, there was no difference between the experimental treatments $(\mathrm{P}>0.05)$, nor were there interactions between seasons and treatments $(\mathrm{P}>0.05)$. 
Figure 5. Levels of blood urea nitrogen (BUN) (a) and blood glucose (b) in heifers supplemented with molasses blocks or Control treatments during the dry and the rainy seasons (Experiment 1).

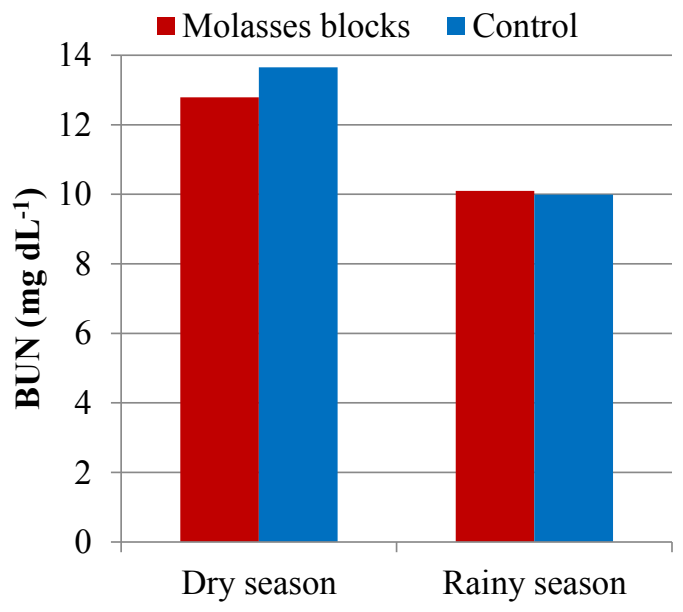

(a)

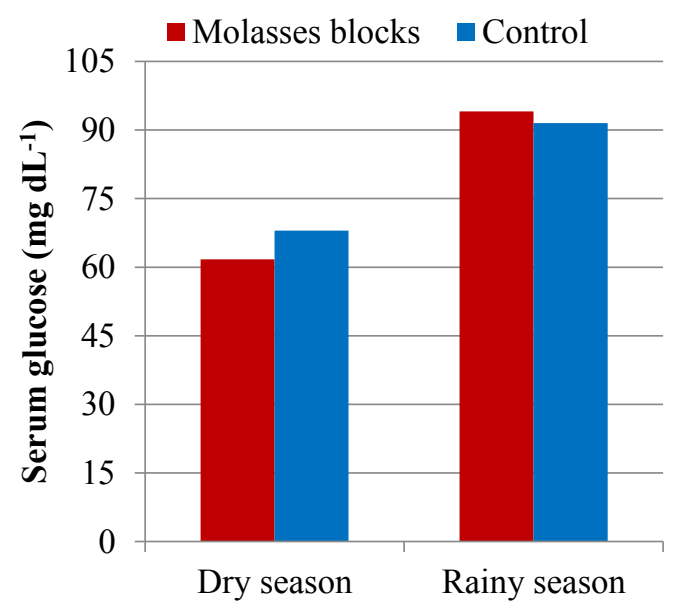

(b)
During the period of BUN analysis data collection, in the dry season (when the heifers received nitrogen supplementation as part of both treatments), the supplement intake averages for the molasses block and control groups were $336 \mathrm{~g}$ day $^{-}$ ${ }^{1}$ per heifer (30\% CP; $60.5 \mathrm{~g}$ urea) and $90 \mathrm{~g} \mathrm{day}^{-1}$ (50\% CP; $22.5 \mathrm{~g}$ urea), respectively, which led to improvements in BUN. In turn, the supplement intake averages during the rainy season were 214 $\mathrm{g} \mathrm{day}^{-1}$ per heifer $(12 \% \mathrm{CP} ; 60.5 \mathrm{~g}$ urea) in the molasses block group and $60 \mathrm{~g}^{-1 a y^{-1}}$ per heifer $(0 \%$ $\mathrm{CP} ; 0 \mathrm{~g}$ urea) for the control group.

The effect was the opposite regarding glucose, the level of which increased during the rainy season $(P<0.05)$ for both supplements because of the natural improvement of forage quality during the rainy season (Table 3), as shown in Figure 5b. There was no difference in blood glucose between treatments $(\mathrm{P}>0.05)$, nor were there interactions between treatments and seasons $(\mathrm{P}>0.05)$.

In Australia, an experiment that involved 12-to-16-month-old heifers (Bos indicus x Bos taurus), with an initial live weight of $191 \mathrm{~kg}$ and grazing paddocks of 12 to $15 \mathrm{ha}$ at the end of the rainy season, showed positive effects regarding a molasses-based supplement with the addition of $13.7-19.5 \%$ phosphoric acid. The measured intakes were 476 and $256 \mathrm{~g}$ day $^{-1}$ per animal, with average weight gains of 0.29 and $0.23 \mathrm{~kg} \mathrm{day}^{-1}$ per heifer, respectively (DIXON, 2013). In the present study, molasses block intake during the 480 experimental days was $242 \mathrm{~g}$ day $^{-1}$ per heifer, and the mean weight gain was $0.290 \mathrm{~kg}$ day $^{-1}$, findings that corroborate the results reported by Dixon (2013). In that study, BUN was $42 \mathrm{mg} \mathrm{L}^{-1}\left(4.2 \mathrm{mg} \mathrm{dL}^{-1}\right)$ in non-supplemented heifers, $66 \mathrm{mg} \mathrm{L}^{-1}\left(6.6 \mathrm{mg} \mathrm{dL}^{-1}\right)$ when urea ingestion was $24 \mathrm{~g} \mathrm{day}^{-1}$ and $110 \mathrm{mg} \mathrm{L}^{-1}$ (11 $\mathrm{mg} \mathrm{dL}^{-1}$ ) when urea ingestion was $38 \mathrm{~g}$ day $^{-1}$ (DIXON, 2013). These results are lower than the current data during the rainy season and differ from our results where supplemented (18.6 g urea intake) and non-supplemented heifers displayed similar BUN values.

Several experiments have been conducted to test supplementation with molasses blocks in animals fed poor roughage. Greenwood et al. (2000) carried out an experiment with steers who received Prairie hay with 5.9\% CP. Supplemented animals received $330 \mathrm{~g}$ of cooked molasses blocks with $30.7 \%$ CP. The results showed that molasses 
block supplementation improved hay intake $(4.88$ and $5.81 \mathrm{~kg} \mathrm{DM}$ day $^{-1}$ for control and supplement, respectively). Leupp et al. (2005) tested the same supplement brand used in the present study. Steers were fed with Switchgrass hay (6\% CP and 74.7\% NDF), and some received supplementation. Those who received supplements consumed $341 \mathrm{~g}$ day $^{-1}$ molasses blocks and exhibited improved hay intake and increased ruminal ammonia levels and ruminal degradability.

Another experiment was conducted to examine supplementation with prairie hay $(5.5 \% \mathrm{CP})$ and $20.0 \mathrm{~g}$ day $^{-1} \mathrm{NaCl}$ per steer. Steers initially weighed $268 \mathrm{~kg}$, and the supplemented steers consumed an average of $320 \mathrm{~g} \mathrm{day}^{-1}$ of a cooked molasses block supplement $(61.2 \% \quad \mathrm{CP})$. Supplemented steers exhibited improved hay intake (5.83 versus $\left.4.74 \mathrm{~kg} \mathrm{day}^{-1}\right)$ and DM digestibility $(59.8 \%$ versus 49.6\%) compared to control (LOEST et al., 2001). The present results did not show advantages in molasses block supplementation during the dry season. Both supplements (molasses blocks and proteinated minerals) failed to help the heifers maintain their weight when the pastures were of an inferior composition at the end of the dry season. New studies are needed to elucidate this problem.

The cows from the molasses block treatment group exhibited higher ruminal temperatures $(\mathrm{P}<$ 0.05) when compared with those from the control treatment (Figure 6). The observed difference probably occurred due to the effect of increased fermentation caused by molasses block intake, whereas the control treatment did not include energetic supplements.

Figure 6. Adjusted mean ruminal temperatures of Nellore cows who consumed molasses blocks or control treatment throughout the day (Experiment 2).

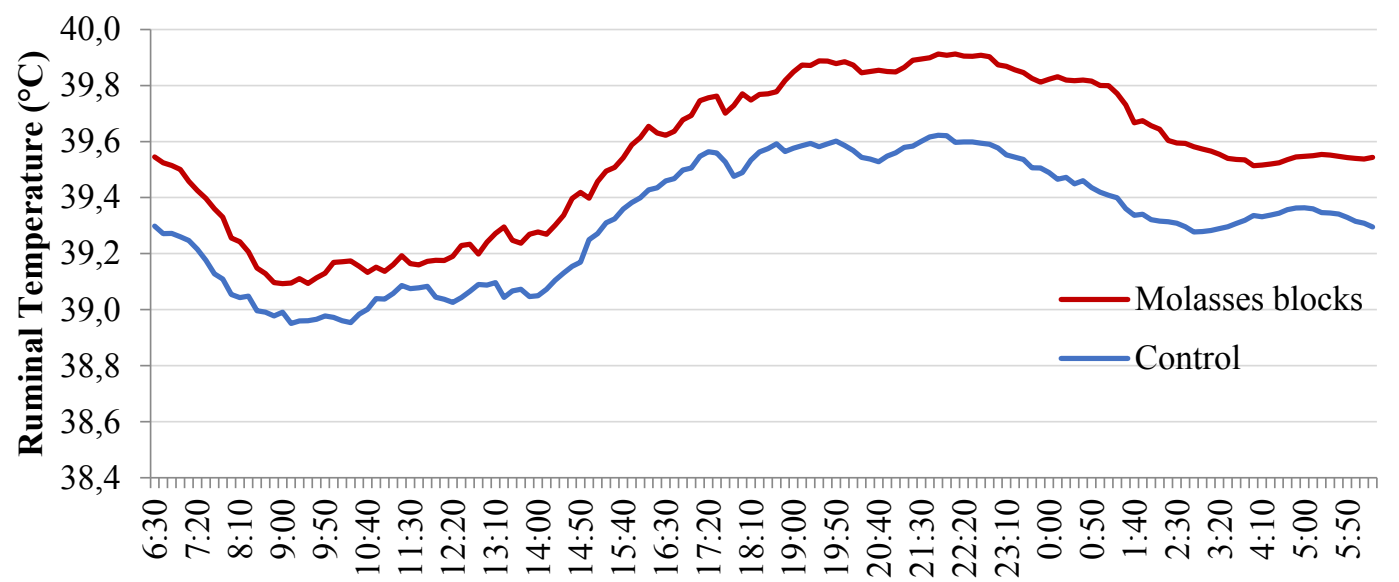

Time of Day

The mean ruminal temperature were $39.5^{\circ} \mathrm{C}$ and $39.3^{\circ} \mathrm{C}$ for the molasses block and control groups, respectively. When comparing the results throughout the entire day, there were no significant differences between the ruminal temperatures from 0800-0930 and 1040-1150. The animals began to graze immediately at dawn (approximately 0630 Brazilian daylight savings time), and stopped between 0900-0930. Subsequently, they would lie down to ruminate, drink water and alternate with short grazing periods. At the end of the day, or early in the evening, at around 1800, they grazed for a second, longer period. Finally, at dusk, all the animals would lie down to rest and ruminate, during which time the greatest differences in the ruminal temperatures between treatments were observed. 
The increase in ruminal temperature due to diets with higher fermentation potential was demonstrated in a German study carried out with non-lactating German Holstein cows (LOHÖLTER et al., 2013). The authors supplied the animals with two diets: 9.7\% CP and $44.7 \% \mathrm{NDF}$ or $14.4 \% \mathrm{CP}$ and $33.3 \%$ NDF. The cows that consumed the more fibrous diet displayed an average temperature of $38.9^{\circ} \mathrm{C}$, while the others retained a higher temperature (mean of $39.3^{\circ} \mathrm{C}$ ). In that study, the most significant differences occurred up to $5 \mathrm{~h}$ after feeding, and the smallest differences occurred during feeding time and up to $30 \mathrm{~min}$ after, similar to the present study.
Ruminal temperature was also used to calculate the frequency in which the cows drank water (Figure 7). The cows supplemented with molasses blocks exhibited more drinking events $(\mathrm{P}<0.05)$ than the control group. Specifically, molasses-blocksupplemented cows drank an average of 3.3 times per day, while control cows drank 3.0 times per day. Time of day significantly affected drinking events $(\mathrm{P}<0.05)$. The incidence of all-day light rains, combined with maximal environmental temperature of $20-25^{\circ} \mathrm{C}$ (Figure 1), dramatically affected the frequency in which the animals drank water, as noted on November $13^{\text {th }}$ and $14^{\text {th }}$ (Figure 7 ).

Figure 7. Adjusted mean number of drinking events per day for the molasses block and control treatment groups (Experiment 2).

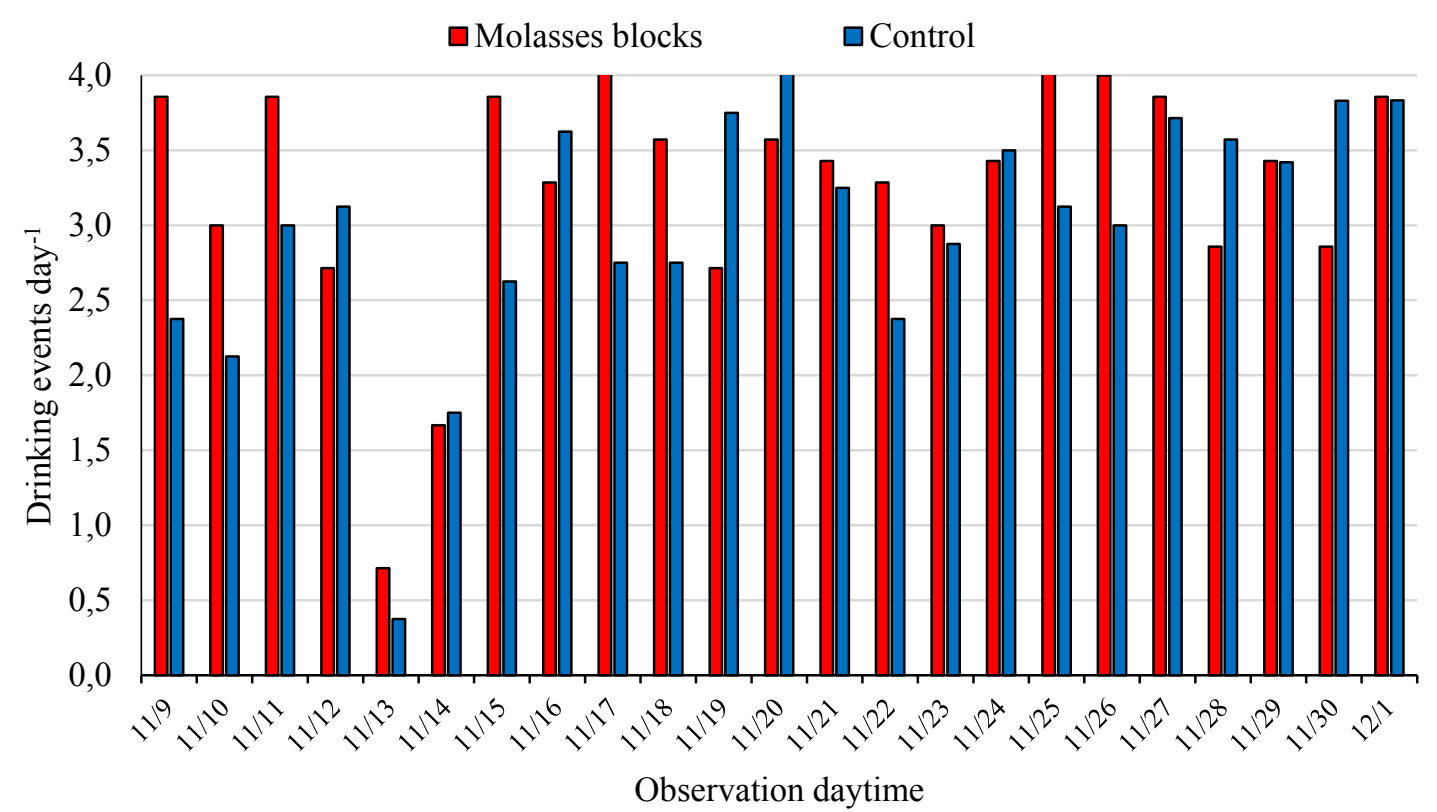

A test performed in Brazil to evaluate the ruminal temperature device employed in the study, for Holstein Friesian dairy cows producing from 30 to $48 \mathrm{~L}^{-1 a y^{-1}}$ of milk, obtained ruminal temperatures between $38.8-39.1{ }^{\circ} \mathrm{C}$ and drinking events from 6.49.5 times per day. The cow that displayed more drinking events was not healthy and exhibited left displacement of the abomasum (GASTEINER et al., 2015). In the present assessment, the frequency of drinking events was lower ( 3 and 3.3 times day
1) when compared with the results reported by Gasteiner et al. (2015).

Additionally, there was a very interesting climate influence regarding the frequency of drinking events. On wet and rainy days, the cows practically did not drink water. Further, the fact that the blocks were positioned near the drinking trough may have contributed to the visitation of the cows to the area and increased the frequency of drinking. 


\section{Conclusion}

Molasses blocks effectively increased Nellore female performance during the rainy season in Marandu grass pastures.

\section{Acknowledgements}

The present study was financed by CAPES, with a scholarship for a graduate student, FUNEP (Grant number 2016-1549) and Caltech-Crystalyx (U.K.)

\section{Conflict of interest}

The authors declare that they have no conflicts of interest.

\section{References}

ASSOCIATION OF OFFICIAL ANALYTICAL CHEMISTS - AOAC. Official methods of analysis of the association of the analytical chemists. Washington: AOAC, 1990. $771 \mathrm{p}$.

AUBEL, N. A.; JAEGER, J. R.; DROUILLARD, J. S.; SCHLEGEL, M. D.; PACHECO, L. A.; LINDEN, D. R.; BOLTE, J. W.; HIGGINS, J. J.; OLSON K. C. Effects of mineral-supplement delivery system on frequency, duration, and timing of supplement use by beef cows grazing topographically rugged, native rangeland in the Kansas Flint Hills. Journal of Animal Science, Oxford, v. 89 , n. 3, p. 3699-3706, 2011. DOI: 10.2527/jas.20103808

BAILEY, D. W.; JENSEN, D. Method of supplementation may affect cattle grazing patterns. Rangeland Ecology Management, New York, v. 61, n. 1, p. 131-135, 2008. DOI: $10.2111 / 06-167.1$

CONSELHO NACIONAL DE CONTROLE DE EXPERIMENTAÇÃO ANIMAL - CONCEA. Resolução Normativa $\mathrm{N}^{\circ} 12$ de 20 de Setembro de 2013. Sociedade Brasileira da Ciência em Animais de Laboratório, Brasil. Brasília, DF, 2013. Disponível em: http://www.icmbio.gov.br/ran/images/stories/legislacao/ RESOLU $\% \mathrm{C} 3 \% 87 \% \mathrm{C} 3 \% 83 \mathrm{O}$ NORMATIVA No_12_-_20-09-2013.pdf. Acesso em: 15 ago. 2018.

COSTA, K. A. P.; ROSA, B.; OLIVEIRA, I. P.; CUSTÓDIO, D. P.; SILVA, D. C. Efeito da estacionalidade na produção de matéria seca e composição bromatológica da Brachiaria brizantha cv. Marandu. Ciência Animal
Brasileira, Goiânia, v. 6, n. 3, p. 187-193, 2005.

DIXON, R. M. Controlling voluntary intake of molassesbased supplements in grazing cattle. Animal Production Science, Victoria, v. 53, n. 3, p. 217-225, 2013. DOI: 10.1071/AN12130

GASTEINER, J.; FALLAST, M.; ROSENKRANZ, S.; HÄUSLER, J.; SCHNEIDER, K.; GUGGENBERGER, T. Zum Einsatz einer intraruminalen $\mathrm{pH}$-Datenmesseinheit mit kabelloser Datenübertragung bei Rindern unter verschiedenen Fütterungsbedingungen. Veterinary Medicine, Viena, v. 96, p. 188-194, 2009.

GASTEINER, J.; GUGGENBERGER, T.; VARGA, L.; OLLHOFF, R. D. Continuous and long term measurement of reticuloruminal $\mathrm{pH}$ in crossbreed dairy cows in Brazil by an indwelling and wireless data transmitting unit. Arquivos Brasileiro de Medicina Veterinária e Zootecnia, Belo Horizonte, v. 67, n. 2, p. 622-626, 2015. DOI: $10.1590 / 1678-7795$

GREENWOOD, R. H.; TITGEMEYER, E. C.; DROUILLARD, J. S. Effects of base ingredient in cooked molasses blocks on intake and digestion of prairie hay by beef steers. Journal of Animal Science, Oxford, v. 78, n. 1, p. $167-172$, 2000. DOI: $10.2527 / 2000.781167 x$

JAYAWICKRAMA，D. R.; WEERASINGHE，P. B.; JAYASENAD, D.; MUDANNAYAKE, D. C. Effects of supplementation of urea-molasses multinutrient block (UMMB) on the performance of dairy cows fed good quality forage based diets with rice straw as a night feeding. Journal of Agricultural Science, Cambridge, v. 40, n. 2, p. 123-129, 2013. DOI: 10.7444/ cnujas.2013.40.2.123

KALMBACHER, R. S.; BROWN, W. F.; PATE, F. M. Effect of molasses-based liquid supplements on digestibility of creeping bluestem and performance of mature cows on winter range. Journal of Animal Science, Oxford, v. 73, n. 3, p. 853-860, 1995. DOI: $10.2527 / 1995.733853 x$

LANDBLOM, D. G.; RINGWALL, K.; HELMUTH, K.; POLAND, W. W.; LARDY, G. P. Effect of fat source and supplement delivery method on beef cowcalf performance and reproductive responses. In: ANNUAL REPORT BEEF SECTION, 2002, Dickinson. Proceeding... Dickinson: NDSU, North Dakota State University, 2002. p. 300-308.

LEUPP, J. L.; CATON, J. S.; SOTO-NAVARRO, S. A.; LARDY, G. P. Effects of cooked molasses blocks and fermentation extract or brown seaweed meal inclusion on intake, digestion, and microbial efficiency in steers fed low-quality hay. Journal of Animal Science, Oxford, v. 83 , n. 12, p. 2938-2945, 2005. DOI: $10.2527 / 2005.83122938 \mathrm{x}$ 
LOEST, C. A.; TITGEMEYER, E. C.; DROUILLARD, J. S.; LAMBERT, B. D.; TRATER, A. M. Urea and biuret as nonprotein nitrogen sources in cooked molasses blocks for steers fed prairie hay. Animal Feed Science and Technology, New York, v. 94, n. 3, p. 115-126, 2001. DOI: 10.1016/S0377-8401(01)00312-1

LOHÖLTER, M.; REHAGE, R.; MEYER, U.; LEBZIEN, P.; REHAGE, J.; DÄNICKE, S. Evaluation of a device for continuous measurement of rumen $\mathrm{pH}$ and temperature considering localization of measurement and dietary concentrate proportion. Landbauforsch Applied Agriculture Forestry Research, Hamburg, v. 63, n. 1, p. 61-68, 2013.

MENGISTU, G.; HASSEN, W. Review on: supplementary feeding of urea molasses multi-nutrient blocks to ruminant animals for improving productivity.
International Journal of Animal Husbandry and Veterinary Science, Bhopal, v. 2, n. 6, p. 43-49, 2017.

NATIONAL RESEARCH COUNCIL - NRC. Nutrient requirements of beef cattle. $7^{\text {th }}$ ed. Washington: National Academies Press, 2000. 242 p.

PERDOCK, H. B.; LENG, R. A. Effect the supplementation with protein meal on growth of cattle given a basal diet of untreated or ammoniated rice straw. Asian-Australasian Journal of Animal Science, Seoul, v. 3, n. 4, p. 269-279, 1990. DOI: 10.5713/ajas.1990.269

STEPHENSON, M. B.; BAILEY, D. W.; HOWERY, L. D.; HENDERSON, L. Efficacy of low-stress herding and low-moisture block to target cattle grazing locations on New Mexico rangelands. Journal of Arid Environments, Chubut, v. 130, n. 10, p. 84-93, 2016. DOI: $10.1016 /$ j. jaridenv.2016.03.012 